\title{
Sublethal Effects of Butylated Hydroxytoluene through Feed in Common Carp
}

\author{
Deng-Fwu Hwang, ${ }^{* 1}$ Ming-Rong Tsai, ${ }^{* 1}$ Sen-Shyong Jeng, ${ }^{* 1}$ \\ Harumi Imamura Kojima, ${ }^{* 2}$ and Tamao Yoshida*s
}

(Received December 18, 1990)

\begin{abstract}
Attempts were made to elucidate the sublethal responses of common carp Cyprinus carpio exposed to the feed additive butylated hydroxytoluene (BHT). The common carp was administered BHT at sublethal levels such as $0.2-1.6 \%$ in the diet for 14 weeks. The growth rate was not found to significantly decrease when common carp were fed a diet with supplements of BHT $(p>0.05)$. However, the declining growth rate was observed to be most significant in the fish fed diet with supplement of $1.6 \%$ BHT from the 4 th to 8 th weeks $(p<0.05)$. The symptoms of hepatopancreas enlargement were commonly found in the fish group fed diet with supplement of BHT. However, this symptom would be alleviated when the fish were switched to the BHT-free dietThe pathological symptoms in hepatopancreas induced by BHT were observed under microscope. The lesions indicated that the enlarged hepatopancreas had heavy steatosis, eosinophilia, and megalocytic hepatosis.
\end{abstract}

The synthetic antioxidant butylated hydroxytoluene (BHT) has been widely used as an additive to food and animal feed for the purpose of preventing autoxidation of fatty acids. Investigators in 1965 already revealed that BHT only developed a low order of acute toxicity causing liver enlargement in rats. ${ }^{1}$ During the latter half of the last decade, intensive studies were conducted on its toxicological features, mostly in rodents. It has been shown to significantly induce mixed-function oxidases and at the same time to cause liver enlargement in rats ${ }^{4 j}$ while necrosis in the livers of male mice has also been recognized. ${ }^{3)}$

Although the other antioxidant such as ethoxyquin is popularly used in fish feed in Japan, BHT is popularly used in fish feed in Taiwan. The safety of BHT used in the feed for fish, however, has not been studied so far. As is known, xenobiotic metabolism in aquatic organisms is usually slower than that in terrestrial animals." In order to establish whether BHT produces hepatic damage or other effects in fish, the responses of common carp to BHT were studied after oral administration of BHT through feed.

\section{Materials and Methods}

One thousand specimens of the common carp Cyprinus carpio were obtained from the Aquaculture Department of Wu-shan-tour Dam, Tawan Fishery Bureau. The fish were acclimated in several aquaria $(60 \times 60 \times 45 \mathrm{~cm})$ with open circulating system for one month under the laboratory conditions with normal feed. The fish, about $1.4 \mathrm{~g}$ of body weight, were divided into 5 groups of 60 fish each. Each group was separately administered feed with supplement of $0,0.2 \%, 0.4 \%, 0.8 \%$ and $1.6 \%$ BHT (Merck) for 14 weeks. The formulation of feed is shown in Table 1. The fish were given the feed at the ratio of $5 \%$ of body weight daily for a period of $0-10$ weeks and $4 \%$ of body weight for a period of 11-14 weeks. Water temperature was controlled at $25-2 \mathrm{C}$. The weight of whole body and hepatopancreas of six fish specimens were measured every two weeks, then the amount of feed given to the fish was adjusted. All fish survived throughout the experiment. After 14 weeks of culture, hepatopancreas enlargement was found in every group of fish fed diet with supplement of BHT. Among them, the fish of the

*I Graduate School of Marine Food Science, National Taiwan Ocean University, Pei-Ning Road,

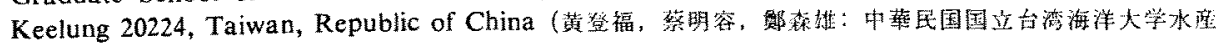
食品科学研究所).

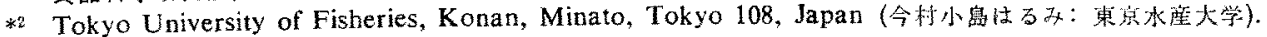

*3 Department of Aquaculture, National Taiwan Ocean University, Pei-Ning Road, Keelun 20224,

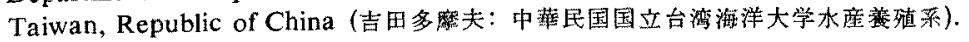


Table 1. Formulation and chemical analysis of experimental diets

\begin{tabular}{|c|c|c|c|c|c|}
\hline \multirow{2}{*}{$\frac{\text { Components }}{\text { BHT }}$} & \multicolumn{5}{|c|}{$\begin{array}{l}\text { Percentage of component } \\
\text { in the diets }\end{array}$} \\
\hline & 0.0 & 0.2 & 0.4 & 0.8 & 1.6 \\
\hline Casein & 33.0 & 33.0 & 33.0 & 33.0 & 33.0 \\
\hline Dextrin & 25.0 & 25.0 & 25.0 & 25.0 & 25.0 \\
\hline$\alpha$-Potato starch & 25.0 & 24.8 & 24.6 & 24.2 & 23.4 \\
\hline Cellulose & 5.5 & 5.5 & 5.5 & 5.5 & 5.5 \\
\hline Oil ${ }^{* 1}$ & 5.0 & 5.0 & 5.0 & 5.0 & 5.0 \\
\hline Salt mixture $* 2$ & 4.0 & 4.0 & 4.0 & 4.0 & 4.0 \\
\hline Vitamin mixture $* 3$ & 1.0 & 1.0 & 1.0 & 1.0 & 1.0 \\
\hline Sodium alginate & 1.5 & 1.5 & 1.5 & 1.5 & 1.5 \\
\hline Moisture & 11.1 & 10.0 & 11.8 & 10.0 & 9.4 \\
\hline Protein & 30.5 & 30.3 & 30.9 & 30.4 & 30.6 \\
\hline Lipid & 5.2 & 5.9 & 5.8 & 6.8 & 6.4 \\
\hline Ash & 3.5 & 3.4 & 4.0 & 3.6 & 3.1 \\
\hline Carbohydrate & 50.2 & 50.4 & 47.4 & 49.2 & 50.5 \\
\hline \multicolumn{6}{|l|}{$* 1$ Oil: soybean oil +} \\
\hline $\begin{array}{l}\text { *2 Salt mixture: }(\mathrm{g} / \\
\mathrm{CuCl}_{2} 0.0004 ; \mathrm{K} \\
\mathrm{H}_{2} \mathrm{O} 0.0032 ; \mathrm{Zn} \\
\mathrm{NaCl} 0.1740 ; \mathrm{N} \\
0.5480 ; \mathrm{KH}_{2} \mathrm{PO}_{4}\end{array}$ & $\begin{array}{l}0.0006 \\
\mathrm{O}_{4} \cdot 7 \mathrm{H}_{2} \mathrm{O} \\
\mathrm{H}_{2} \mathrm{PO}_{4} \mathrm{O} \\
9572 ; \mathrm{C}\end{array}$ & $\begin{array}{r}0.0120 \\
3488 ; \mathrm{C} \\
\text { lcium la }\end{array}$ & $\begin{array}{l}\mathrm{OH}_{3} \mathrm{O} \\
; \text { ferric } \\
\text { aHPO } \\
\text { actate } 1.3\end{array}$ & $\begin{array}{l}0040 ; \mathbb{N} \\
\text { citrate } \\
.5432 \\
080 .\end{array}$ & $\begin{array}{l}0.0006 \\
\mathrm{InSO}_{4} \\
0.1188 \\
\mathrm{MgSO}_{4}\end{array}$ \\
\hline \multicolumn{6}{|c|}{$\begin{array}{l}\text { acid } 45 \text {; pyridoxine- } \mathrm{HCl} 40 \text {; thiamin- } \mathrm{HCl} 60 ; d \text {-pantothena } \\
\text { te } 280 \text {; p-aminobenzoic acid } 400 \text {; nicotinic acid } 800 ; 1 \text { - } \\
\text { ascorbic acid } 2000 \text {; myo-inositol } 4000 \text {; riboflavin } \mathrm{B}_{2} 200 \text {; } \\
\text { menadione } 40 \text {. }\end{array}$} \\
\hline \multicolumn{6}{|l|}{$* \quad C$} \\
\hline
\end{tabular}

$0.2 \%$ and $1.6 \%$ BHT groups were switched to the control diet, which contained no BHT, for 2 weeks and the ability to recover from pathological symptoms were examined.

After 14-week culture, histopathological diagnosis of hepatopancreas of control and $0.2 \%$ BHT groups was performed. The hepatopancreas was treated with $10 \%$ neutral buffered formalin. The tissues embedded in paraplast were sectioned at $6 \mu \mathrm{m}$ with a rotation microtome (Shandon Southern Products Ltd., England). The sections were stained with hematoxylin for $5 \mathrm{~min}$ and $0.5 \%$ eosin for $3 \mathrm{~min}$ before mounting in euparal for microscopy. The fish fed $0.2 \%$ BHT for 14 weeks and then switched to BHT free-diet for 2 weeks were also examined.

\section{Results}

Effects of BHT on the growth of common carp for 14 weeks are shown in Table 2. After feeding for 14 weeks, the growth rate was not significantly different in any fish groups $(p>0.05)$. However, a declining growth rate was observed to be significant in the fish fed diet with supplement of $1.6 \%$ BHT from the 4 th to 8 th weeks $(p<0.05)$. It was also found that the average growth rate seemed to be lower in all fish groups receiving diet with supplement of BHT. At the 14th week, the body weight of fish fed diet with supplement of $1.6 \% \mathrm{BHT}$ was about $83.5 \%$ of that of fish in the control group. Feed conversion efficiency decreased when the common carp were fed diet with supplement of BHT but it was not significant $(p>0.05)$. Effect of BHT on the ratio of hepatopancreas weight to body weight (hepatosomatic index) in common carp is shown in Table 3. After feeding for 2 weeks, enlargement of fish hepatopancreas was more clearly observed in both $0.8 \%$ and $1.6 \%$ BHT groups than in other groups. After feeding for 12 weeks, this phenomenon was observed to be more significant in all groups fed diets with supplements of BHT than in the control group. After 14 weeks, the average hepatopancreas enlargement was about $36.4 \%$ of that of the control group.

As mentioned above, the hepatopancreas in common carp fed diets with supplements of BHT was markedly enlarged. In order to know how to recover from pathological symptoms in hepatopanceras, the fish groups fed diet with supplements

Table 2. Effect of BHT on the growth of common carp Cyprinus carpio

\begin{tabular}{|c|c|c|c|c|c|}
\hline \multirow[t]{2}{*}{ Weeks } & \multicolumn{3}{|c|}{ Body weight $(\mathrm{g})^{*}$} & \multirow[b]{2}{*}{$0.8 \%$ ВНТ } & \multirow[b]{2}{*}{$1.6 \% \mathrm{BHT}$} \\
\hline & Control & $0.2 \% \mathrm{BHT}$ & $0.4 \% \mathrm{BHT}$ & & \\
\hline 2 & $1.83 \pm 0.35^{a}$ & $1.83 \pm 0.32^{a}$ & $1.80 \pm 0.31^{\mathrm{a}}$ & $1.76 \pm 0.22^{\mathrm{a}}$ & $1.73 \pm 0.28^{a}$ \\
\hline 4 & $2.47 \pm 0.52^{u}$ & $2.40 \pm 0.44^{\mathrm{x}}$ & $2.45 \pm 0.47^{\mathrm{a}}$ & $2.39 \pm 0.46^{\mathrm{a}}$ & $2.18 \pm 0.40^{\mathrm{b}}$ \\
\hline 10 & $6.62 \pm 1.55^{\mathrm{a}}$ & $6.59 \pm 1.39^{\mathrm{a}}$ & $6.48 \pm 1.41^{\mathrm{a}}$ & $6.24 \pm 1.09^{\mathrm{a}}$ & $6.00 \pm 1.20^{\mathrm{a}}$ \\
\hline 12 & $9.12 \pm 2.11^{\mathrm{a}}$ & $8.89 \pm 2.03^{\mathfrak{a}}$ & $8.80 \pm 2.27^{\mathrm{a}}$ & $8.48 \pm 1.92^{\mathrm{a}}$ & $7.88 \pm 1.74^{\mathrm{a}}$ \\
\hline 14 & $12.40 \pm 2.33^{a}$ & $12.20 \pm 2.82^{\mathrm{a}}$ & $12.00 \pm 3.38^{\mathrm{B}}$ & $11.57 \pm 2.55^{\mathrm{a}}$ & $10.39 \pm 2.38^{a}$ \\
\hline
\end{tabular}

* Values in the same row having different superscripts are significantly different $(p<0.05)$. 
Table 3. Effect of BHT on the hepatopancreas weight change of common carp Cyprinus carpio

\begin{tabular}{clllll}
\hline \multirow{2}{*}{ Weeks } & \multicolumn{5}{c}{ Hepatosomatic index $(\%)^{* 1}$} \\
\cline { 2 - 6 } & Control & $0.2 \%$ BHT & $0.4 \%$ BHT & $0.8 \%$ BHT & $1.6 \%$ BHT \\
\hline 0 & $1.21 \pm 0.24^{\mathrm{a} * 2}$ & $1.20 \pm 0.20^{\mathrm{a}}$ & $1.23 \pm 0.50^{\mathrm{a}}$ & $1.22 \pm 0.32^{\mathrm{a}}$ & $1.20 \pm 0.40^{\mathrm{a}}$ \\
2 & $1.32 \pm 0.20^{\mathrm{a}}$ & $1.27 \pm 0.25^{\mathrm{a}}$ & $1.45 \pm 0.48^{\mathrm{ab}}$ & $1.79 \pm 0.18^{\mathrm{b}}$ & $2.15 \pm 0.65^{\mathrm{b}}$ \\
4 & $1.29 \pm 0.50^{\mathrm{a}}$ & $1.35 \pm 0.31^{\mathrm{a}}$ & $1.71 \pm 0.51^{\mathrm{ab}}$ & $1.70 \pm 0.71^{\mathrm{ab}}$ & $2.45 \pm 0.62^{\mathrm{b}}$ \\
6 & $1.43 \pm 0.15^{\mathrm{a}}$ & $1.58 \pm 0.15^{\mathrm{ab}}$ & $2.02 \pm 0.71^{\mathrm{ab}}$ & $2.16 \pm 0.55^{\mathrm{b}}$ & $2.15 \pm 0.25^{\mathrm{b}}$ \\
8 & $1.99 \pm 0.38^{\mathrm{ab}}$ & $1.97 \pm 0.31^{\mathrm{a}}$ & $2.07 \pm 0.77^{\mathrm{ab}}$ & $2.34 \pm 0.89^{\mathrm{ab}}$ & $2.73 \pm 0.74^{\mathrm{b}}$ \\
10 & $2.30 \pm 0.42^{\mathrm{a}}$ & $3.19 \pm 0.54^{\mathrm{b}}$ & $3.14 \pm 0.53^{\mathrm{b}}$ & $2.97 \pm 0.75^{\mathrm{ab}}$ & $3.52 \pm 0.91^{\mathrm{b}}$ \\
12 & $2.42 \pm 0.25^{\mathrm{a}}$ & $3.42 \pm 0.50^{\mathrm{b}}$ & $3.20 \pm 0.55^{\mathrm{b}}$ & $3.26 \pm 0.69^{\mathrm{b}}$ & $3.60 \pm 0.67^{\mathrm{b}}$ \\
14 & $2.54 \pm 0.27^{\mathrm{a}}$ & $3.56 \pm 0.35^{\mathrm{b}}$ & $3.24 \pm 0.35^{\mathrm{b}}$ & $3.42 \pm 0.74^{\mathrm{b}}$ & $3.64 \pm 0.78^{\mathrm{b}}$ \\
\hline
\end{tabular}

*1 Hepatosomatic index $(\%)=$ (hepatopancreas weight/body weight $) \times 100$.

*2 Values in the same row having different superscripts are significantly different $(p<0.05)$.

of $0.2 \%$ and $1.6 \%$ BHT for 14 weeks were switched to BHT-free diets for 2 weeks. The enlarged hepatopancreas was found to be easily recovered to

Table 4. The recovering effect of hepatopancreas enlargement in common carp Cyprinus carpio

\begin{tabular}{lll}
\hline \hline Diet treatment & \multicolumn{2}{c}{ Hepatosomatic index (\%) } \\
\cline { 2 - 3 } & 14 weeks $^{* 1}$ & 16 weeks*2 \\
\hline Control diet & $2.54 \pm 0.27^{\mathrm{a} * 3}$ & $2.61 \pm 0.30^{\mathrm{a}}$ \\
$0.2 \%$ BHT diet $\rightarrow$ & $3.56 \pm 0.35^{\mathrm{b}}$ & $2.78 \pm 0.35^{\mathrm{a}}$ \\
$\begin{array}{l}\text { control diet } \\
1.6 \% \text { BHT diet } \rightarrow\end{array}$ & $3.64 \pm 0.78^{\mathrm{b}}$ & $2.80 \pm 0.50^{\mathrm{a}}$ \\
\hline & & \\
\hline
\end{tabular}

$*_{1}$ The fish were separately fed diet with supplement of $0,0.2$, and $1.6 \%$ BHT groups for 14 weeks.

*2 The above fish were then switched to control diet for 2 weeks.

*3 Values in the same column having different superscripts are significantly different $(p<0.05)$. normal wight (Table 4).

The tissues of hepatopancreas of common carp caught in control group, $0.2 \%$ BHT group and recovering group after feeding $0.2 \% \mathrm{BHT}$, were examined under microscope. In normal hepatopancreas of common carp dense hepatocytes were seen and nuclei were clearly observed as shown in Fig. 1. Figure 2 shows the pathological symptoms in the hepatopancreas of fish fed diet with supplement of $0.2 \%$ BHT for 14 weeks. Numerous lesions of necrosis and pycnosis were seen, and lipofuscin-like granules had accumulated in the hepatocytes. Large lipid droplets with a foamy material or granular texture of eosinophilic substances occupied the cytoplasm (presenting the socalled "moth-eaten cytoplasm").s) The nuclei seemed to be markedly enlarged and were not clearly stained. Figure 3 shows the enlarged hepatocytes to be recovering to normal when the

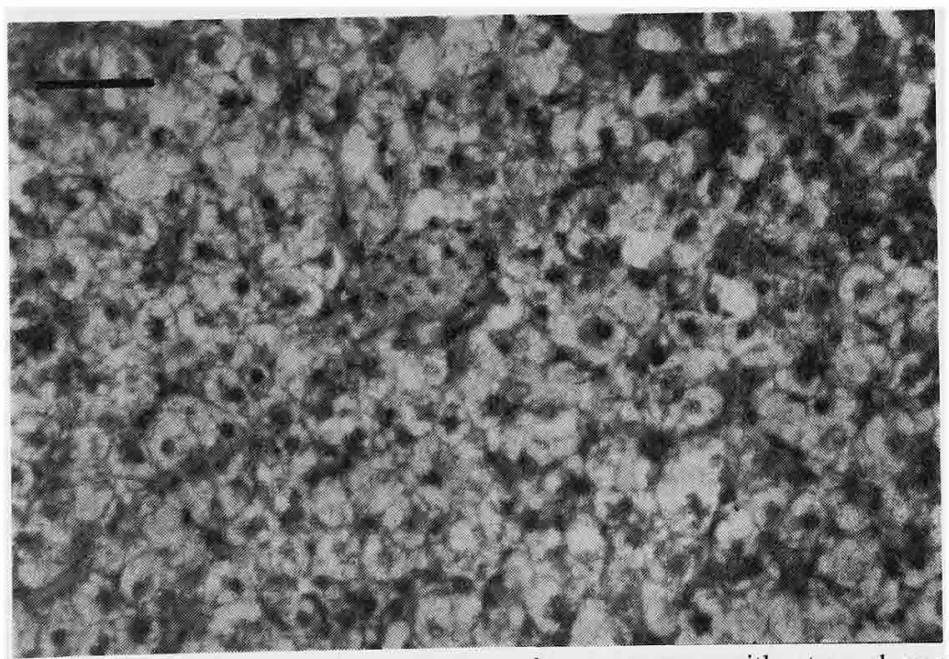

Fig. 1. Microscopic cross-section of common carp hepatopancreas without supplement of BHT for 14 weeks. Bar represents $0.04 \mathrm{~mm}$. 


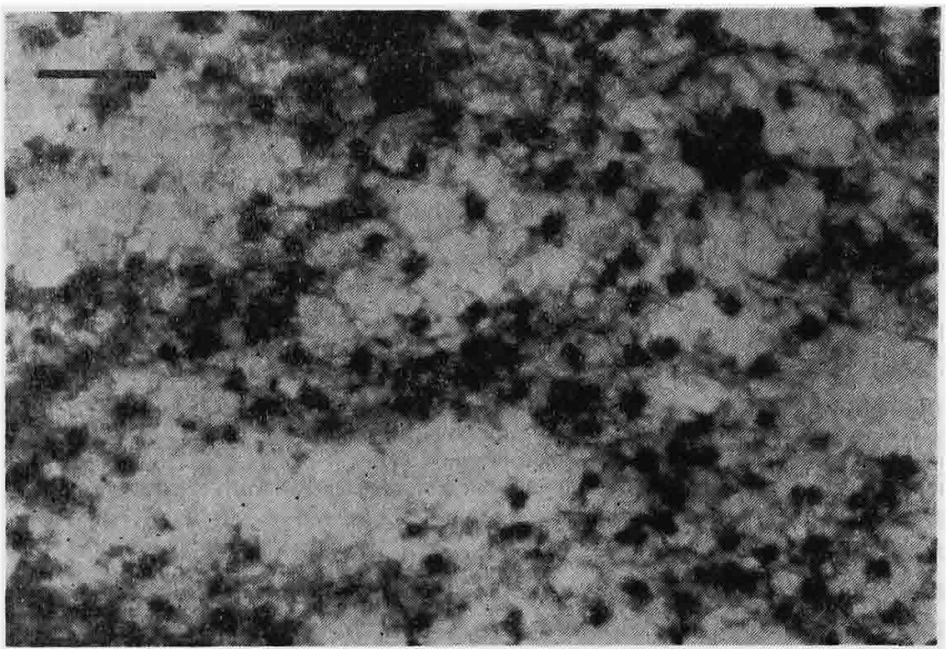

Fig. 2. Microscopic cross-section of common carp hepatopancreas with supplement of $0.2^{\circ} \mathrm{O}$ BHT for 14 weeks. Bar represents $0.04 \mathrm{~mm}$.

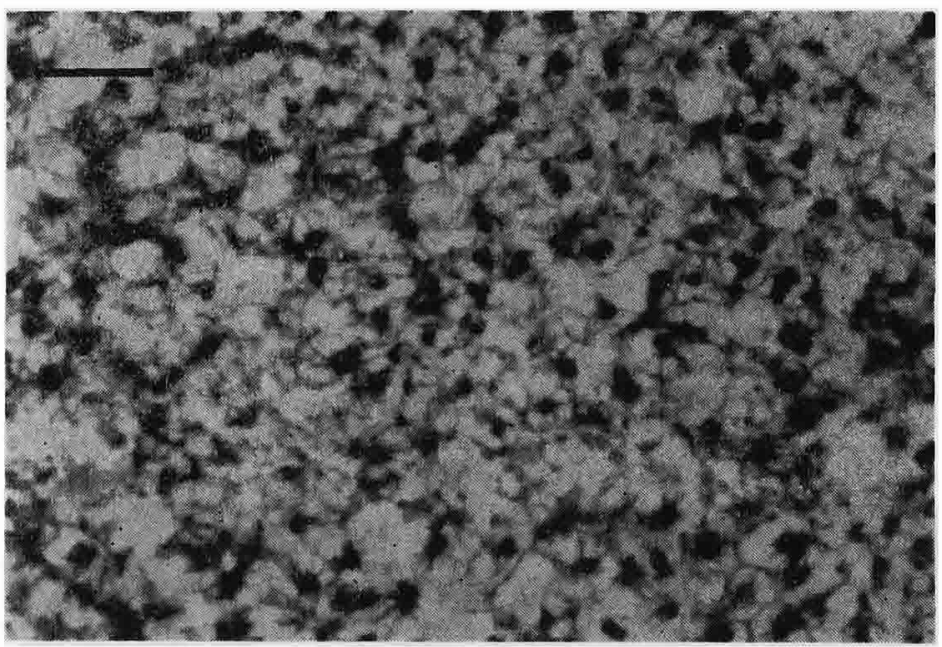

Fig. 3. Microscopic cross-section of common carp hepatopancreas with supplement of $0.2 \%$ BHT for 14 weeks, and then switching to BHT-free diet for 2 weeks. Bar represents 0.04 $\mathrm{mm}$.

fish were fed diets without supplements of BHT. In this case, the nuclei were clearly seen in the hepatocytes but a slight increase in the accumulation of lipid and lipofuscin-like granules deposition in hepatocytes was also observed.

\section{Discussion}

The responses of common carp exposed to sublethal levels of BHT were demonstrated in this study. The growth and feed conversion efficiency were not significantly decreased when the common carp were fed diets with supplement of BHT. BHT obviously produced hepatopancreas enlargement in common carp. These responses are the same as those in the rat. ${ }^{1)}$ It is interesting that recovery of hepatopancreas enlargement in common carp was rapid when the feed was switched to BHT-free. This may indicate that the metabolism of BHT in common carp can be fairly effective. A more detailed study on the fate of BHT in the fish in still progressing in this lab- 
oratory.

From hepatopancreas lesions under light microscope, pathological symptoms induced by BHT in hepatopancreas of common carp included heavy steatosis, eosinophilia, and megalocytic hepatosis. These identical patterns have been reported worldwide, often in connection with liver neoplasms from areas impaired by considerable anthropogenic input of various hepatotoxins, carcinogens, and/or carcinogenic promoters, such as polychlorinated biphenyls (PCBs) and their by-products, hexachlorobenzene (HCB), hexachlorohexane $(\mathrm{HCH})$, and other chlorinated hydrocarbons, as well as polycyclic aromatic hydrocarbons (PAHs). ${ }^{5-123}$

\section{Acknowledgements}

The authors wish to thank the Aquaculture Department of Wu-shan-tour Dam, Taiwan Fishery Bureau for the generous gift of common carp; Prof. Dr. F. Takashima for valuable suggestions in histochemical observation, and also Dr. C.-F. Chang and Dr. B.-Q. Huang, National Taiwan Ocean University, for technical assistance; and Mr. C.-L. Lien and Mr. E.-L. Hsu, National Taiwan Ocean University, for their care of the animals. This work was supported by a grant from the Council of Agriculture (Grant No. COA 79-7.1-F-50-13).

\section{References}

1) D. Gilbert and L. Golberg: Food Cosmet. Toxicol., 3, 417-421 (1965).

2) R. F. Crampton, T. J. B. Gray, P. Grasso, and D. V. Parke: Toxicology, 7, 289-306 (1977).

3) D. Thompson and P. Moldéus: Biochem. Pharmac., 37, 2201-2207 (1988).

4) K. Kobayashi: Kagaku to Seibutsu, 17, 761-769 (1981).

5) A. Kohler: Aquat. Toxicol, 16, 271-294 (1990).

6) S. Falkmer, S. O. Embin, Y. Ostberg, and A. Mattisson: Prog. Exp. Tumor Res., 20, 217-250 (1976).

7) B. B. McCain, K. V. Pierce, S. R. Wellings, and B. S. Miller: Bull. Environ. Contam. Toxicol., 18, 1-29 (1977).

8) C. E. Smith, T. H. Peck, R. J. Klarda, and J. B. McLaren: J. Fish. Dis., 2, 313-319 (1979).

9) K. V. Pierce, B. B. McCain, and S. R. Wellings: J. Natl. Cancer Inst., 69, 1445-1453 (1978).

10) D. C. Malins, B. B. McCain, D.W. Brown, S.-L. Chan, M. S. Meyrs, J. T. Landahl, P. G. Prohaska, A. J. Friedman, L. D. Rhodes, D. G. Burrows, W. D. Gronlund, and H. O. Hodgins: Environ. Sci. Technol., 18, 705-713 (1984).

11) R. A. Murchelano and R. E. Wolke: Science, 228, 587-589 (1985).

12) N. Peters, A. Kohler, and H. Kranz: Dis. Aquat. Org., 2, 87-97 (1987). 